\title{
Childhood Obesity: An Overview
}

\author{
Anugya Bharti* and Kalpana Kulshrestha \\ Department of Foods and Nutrition, GB Pant University of Agriculture and Technology, \\ Pantnagar, Uttarakhand - 263145, India
}

*Corresponding author:

\section{A B S T R A C T}

\section{Keywords}

Childhood, Obesity,

Type 2 diabetes,

Physical activity,

Nutrition education

Article Info

Accepted:

10 December 2018

Available Online:

10 January 2019
Obesity is considered as one of the most serious health challenges of the 21 st century. Obesity in children is an equally significant public health concern. Childhood obesity is increasing at alarming rate every year all over the world. Obesity is defined as condition of excessive fat accumulation in adipose tissue, to an extent that health may be impaired. Childhood obesity has been linked to both environmental and genetic factors. Various factors contributing towards childhood obesity includes consumption of energy dense fast foods, decreased fruits and vegetable intake, shifting to sedentary lifestyle with no physical activity and excessive use of electronic media. Obesity is creating economic and health burden by increasing the risk for health problems such as elevated blood pressure, cardiovascular disease, insulin resistance and type 2 diabetes, respiratory and psychological problems among overweight and obese children. Nutrition education, promotion of physical activity along with behaviour modifications and decrease in sedentary lifestyle among children could be the factors in the prevention of childhood obesity.

\section{Introduction}

\section{Childhood obesity prevalence}

\section{The global picture}

The prevalence of obesity has been increasing worldwide and has almost doubled over the last decade. Overweight is stated as fifth most serious risk factor by WHO report 2000 for both developing countries and developed countries (World Health Organization, 2000). James (2004) stated high prevalence of overweight and obesity was found among people of Middle East, Central and Eastern Europe and North America whereas developing countries are facing double burden of childhood obesity and underweight. High obesity rates have been reported from acquired affluence countries like Taiwan and Saudi Arabia. AlNuaim et al., (1996) stated one in every sixth children of 6 to 18 years of age as obese in Saudi Arabia. High incidence of obesity has also been reported among school children in India. The prevalence of obesity has been found to be $5.74 \%$ to $8.82 \%$ among school children.

\section{Prevalence in India}


The magnitude of childhood obesity has increased very rapidly in India. Estimates of prevalence were studied by Midha et al., (2012) using random effects meta-analysis and prevalence of overweight and obesity was estimated to be $12.64 \%$ and $3.39 \%$.

Ranjani, et al., (2016) reviewed studies conducted in 16 states of India. Data about prevalence of overweight and obesity from 52 studies showed that prevalence of obesity in both children and adolescent was higher in North India as compared to South India. He also found $3 \%$ increase in prevalence of childhood and adolescence obesity from 2005 to 2010 .

Prevalence of childhood obesity among school age children in various parts of India is shown in tabular form in Table 1.

\section{Prevalence in Uttarakhand}

Kumar and Sharma (2013) stated overall prevalence of overweight and obesity to be $14 \%$ and $18 \%$ in Uttarakhand. Baghel et al., (2015) conducted study on 50 school children of Pantnagar and stated overall prevalence of overweight and obesity to be $16 \%$ and $3.80 \%$ in HIG (high income group) and 4\% overweight in MIG ( middle income group).

\section{Childhood obesity and socioeconomic status}

Marwaha et al., (2006) stated higher prevalence of overweight and obesity among upper socioeconomic school children of 5-18 years in Delhi. Prevalence of both overweight and obesity was higher in girls than boys in USES (upper socioeconomic status) whereas boys were having higher prevalence of overweight and obesity in LSES (lower socioeconomic status).

Kaur et al., (2008) conducted a study on
16,595 school children of age 5-18 years belonging to low, middle and high socioeconomic status and found that prevalence of both overweight and obesity increases as the socioeconomic status increases. $9.3 \%$ and $13.1 \%$ obesity and overweight was found in high income group whereas $2.5 \%$ obesity and $4.9 \%$ overweight in middle income group followed by $1.2 \%$ and $2.4 \%$ obesity and overweight in low income group.

\section{Measures of obesity}

\section{Body mass index}

WHO defines obesity as abnormal or excessive fat accumulation (www.who.int/topics/obesity/en/) to an extent that health of a person is impaired. Overweight and obesity increases the risk for a number of chronic diseases, including cardiovascular diseases, diabetes, cancer etc. BMI (Body Mass Index) is the most commonly used method for assessing overweight and obesity in adults as it correlates well with level of body fat. Body Mass Index (BMI) is defined as an individual's weight in kilograms divided by the square of their height in metres (www.noo.org.uk/, 2009).

The World Health Organization (WHO) classifies person with BMI greater than or equal to $25 \mathrm{~kg} / \mathrm{m}^{2}$ as overweight and BMI greater than or equal to $30 \mathrm{~kg} / \mathrm{m}^{2}$ as obese. BMI provides the most useful population-level measure of overweight and obesity as it is the same for both sexes and for all ages of adults (www.who.int/mediacentre) and can be taken easily and speedily in a non- invasive manner. This has lead to the widespread use of BMI in a range of settings. Despite its considerable advantages, BMI has limitations too. The relationship between BMI and body fat is agedependent, the proportion of fat to lean mass 
becomes greater as the age increases. Pallan (2010) stated that BMI overestimate the body fat in very muscular individuals, so, not able to distinguish between fat mass and muscle mass in an individual.

\section{BMI in children}

\section{BMI z - score}

Must and Anderson (2006) stated that BMI z score or Body mass index z-scores or BMI SD score is equivalent to $\mathrm{BMI}$ - for - age percentile. It can be used for determining health status of children if age, sex and BMI for children are known. BMI z- score is not used for clinical practise. Child's BMI-for-age percentile can be determined clinically by using BMI-for-age growth charts for tracking health status of children.

\section{BMI - for - age percentile}

Using height and weight, BMI for children is calculated. Then, BMI is expressed as percentile by using either graph or chart. BMI percentile shows child BMI relative to children of USA who participated in survey conducted at national level from 1963-65 to 1988-94. CDC growth charts (2000) states BMI - for - age percentile for normal child between $5^{\text {th }}$ to $85^{\text {th }}$ percentile whereas below $5^{\text {th }}$ percentile is considered as underweight and above $85^{\text {th }}$ percentile upto less than the $95^{\text {th }}$ percentile are considered in overweight category. Children with $95^{\text {th }}$ percentile or above are considered in obese category.

\section{Other measures of obesity}

\section{Skinfold thickness}

It provides information about subcutaneous fat deposits. Dwyer and Blizzard (1996) stated five sites namely triceps, biceps, subscapular, suprailiac and midaxillary for measuring skinfold thickness. Tricep skinfold is measured at midpoint on the back of upper left arm. Bicep skinfold is measured on the front of upper left arm. Subscapular skinfold is measured just below and laterally to angle of left shoulder blade. Suprailiac skinfold is measured in midaxillary line superior to iliac crest. Midaxillary skinfold is picked up horizontly on midaxillary line, at the level of xiphoid process. Three types of precision callipers are used for measuring skinfold thickness namely: Harpenden, Lange and Holtain. $30 \%$ body mass as fat in case of girls and $20-25 \%$ body fat in case of boys are cut off value stated for obesity.

\section{Waist circumference}

Waist circumference is measure of central obesity. Higgins et al., (2001) conducted study on 4 to 11 years pre- pubertal children and concluded that obese children having waist circumference $>71 \mathrm{~cm}$ and body fat $>33 \%$ possess increased risk for cardiovascular diseases. Adult male with waist circumference $>102 \mathrm{~cm}$ (>40 inches) and for adult women $>88 \mathrm{~cm}$ (>35 inches) shows risk for diabetes, hypertension, heart disease etc.

\section{Waist hip ratio}

Waist hip ratio is waist circumference divided by hip circumference. Waist circumference is measured in lowest rib margin and iliac crest in midaxillary line. Hip circumference is measured at maximum circumference over the buttocks.

\section{Hydrostatic weighing}

In hydrostatic weighing, fat content of a person is determined by displacement of water by a person. This method is costly and nonportable but is highly accurate if it is done correctly and so considered as gold standard for measuring body fat content.

Bioelectrical impedence (BEI) 
In this method, electric current is passed through person's body and the impedance of the electric current is measured by impedance machine. A person with higher fat content has higher insulation. This method is less expensive than hydrostatic weighing but not very reliable for adolescents according to Stang and Story (2005) as percentage of body water is higher in pubertal and pre-pubertal adolescents and so this method is used mainly for adults.

\section{Dual energy X-ray absorptiometry (DEXA)}

Dual energy X-ray absorptiometry (DEXA) measures whole body fat as well as bone mineral density. This method produce small amount of radiation by use of $\mathrm{x}$-ray for measuring body fat but is very expensive. According to Bhave et al., (2004) body fat cut off values in adult male is $>25 \%$ and $>35 \%$ in females.

\section{Air displacement plethysmography(BOD- POD)}

This is a new technique that is sophisticated, accurate, non-invasive and comfortable but is very expensive.

\section{Health consequences of childhood obesity}

\section{Obesity and Cardiovascular disease}

Ho (2009) found that obese children have an increased risk for developing cardiovascular complications such as hypertention (HTN), atherosclerosis (thickening of arterial wall) as well as changes in structure and functioning of left ventricular.

Leptin is a hormone produced by adipocytes of adipose tissue stated by Martins et al., (2015). Leptin decreases food intake and maintain weight balance in body. Obese person tends to develop leptin resistance and ultimately have elevated leptin levels. This causes stimulation of hypothalamus to increase blood pressure through activation of the sympathetic nervous system according to Carlyle et al., (2002). Ibarra (2009) stated that obesity induced HTN causes an increase in peripheral vascular resistance via endothelial dysfunction and the hemodynamic changes occurring during obesity increases the cardiac output. In order to accommodate the demand for increased blood volume, left ventricular chamber dilates more and more and develops left ventricular hypertrophy ( $\mathrm{LVH})$.

Freedman et al., (1999) stated that risk for cardiovascular diseases increases as the quetelet index increases. There is a change in level of diastolic blood pressure, systolic blood pressure, LDL, triglycerides and fasting insulin level. Overweight children (with Quetelet index $>85^{\text {th }}$ percentile) are 2.4 times more likely to have an elevated level of total cholesterol as compared to children with Quetelet index <85th percentile. So, overweight and obese child are at more risk of developing cardiovascular disease.

\section{Obesity and type II diabetes}

During the growth period, there is an increase in number of fat cell. When energy intake exceed energy expenditure, size of fat cell increases. When fat cell reaches their maximum capacity to store fat, it again starts to increase in number (www.jyi.org/issue). According to Qatanani and Lazar (2007), expansion in fat mass causes release of fatty acid and elevation in plasma fatty acid concentration. Competition occurs between increased plasma fatty acid concentration and glucose for oxidative metabolism in insulinresponsive cells and Day and Bailey (2011) stated that it reduces the use of glucose as cellular energy source.

In obesity, triglycerides get deposited in 
subcutaneous adipose tissue. But as the size increases, insulin resistance occur and prevents further subcutaneous lipid accumulation. According to Yaturu (2011), triglycerides then get deposited as ectopic fat, particularly in the liver and skeletal muscle and causes insulin resistance.

Insulin is a hormone secreted by beta cells of islet of Langerhans of Pancreas. Insulin converts glucose into glycogen in liver and help muscles, fat and liver cells to absorb glucose from bloodstream and thus helps to maintain the normal level of blood glucose level (www.niddk.nih.gov). Insulin resistance causes an increase in blood glucose level. Pancreas starts to produce greater and greater amount of insulin in order to maintain normal level of glucose in blood. But elevated blood glucose level is not due to inadequate insulin production by pancreas but due to subcutaneous and ectopic fat deposition. So, pancreas eventually fails to work from exhaustion (www.opposingviews.com).

So, obesity among children and adolescents associated with insulin resistance and insulin deficiency leads to the development of type II diabetes (T2DM) according to Hannon et al., (2005).

\section{Obesity and Respiratory diseases}

Obesity not only causes cardiovascular disease and type II diabetes but also responsible for causing several respiratory diseases. Obesity increases load on the chest wall and abdomen and decreases the lung volume. Obesity can lead to development of asthma or may increase the severity. Obstructive sleep apnea (OSA), obesity-hypoventilation syndrome (OHS), pulmonary hypertension, and pneumonia can also be seen in obese children and adults according to Murugan and Sharma (2008); Réthoret-Lacatis and Janssens (2008); Fiorino and Brooks (2009).

\section{Other physical consequences}

Excess of body weight has adverse effect on growth and health of bones, joints, and muscles. Growth plates regulate the length and shape of bones. Excess of body weight creates stress on growth plate that may lead to arthritis, acute fractures and other serious orthopedic complications such as Slipped Capital Femoral Epiphysis, Blount's Disease, Flat Feet, Impaired Mobility etc. in overweight and obese children and adults according to Wills (2004) and (http://orthoinfo.aaos.org/topic.cfm?topic=A0 0679). Sometimes neurological and dermatological problems are also seen in obese person.

\section{Psychosocial consequences}

Childhood obesity not only increases risk for physical health related problems but also has psychological consequences such as depression and anxiety, self esteem, body dissatisfaction, stigma and discrimination.

\section{Depression and Anxiety}

Russell-Mayhew (2012) stated depression as both cause and consequence of childhood obesity. Childhood overweight and obesity mainly at age of 5 years increases the risk for adult depression according to SánchezVillegas et al., (2010). Yagnik et al., (2014) found that depression is more common in obese girls as increase in body weight gives them feeling of dissatisfaction about their body image. Rofey et al., (2009) found both childhood depression and anxiety to be associated with weight gain.

\section{Self esteem}

Self esteem is defined as confidence in one's own worth or abilities. Strauss (2000) found that while comparing with normal children, overweight/ obese children were found to have 
low level of self esteem because of increased rate of sadness, loneliness and nervousness in these children.

\section{Body dissatisfaction}

Awareness about body size and body dissatisfaction is found to be positively correlated with weight status and is more prominent in older children and adults. Thinner ideal body size is more preferred by overweight/ obese children than normal weight children according to Pallan et al., (2011) and Hatami et al., (2015).

\section{Stigma and discrimination}

Obese children are frequently criticized and teased by their peers and so sometimes remains socially isolated in the school. Studies shows that $1 / 3$ of overweight girls and $1 / 4$ of overweight boys are being teased by their peers at school. Sometimes teachers also show negative attitude towards obese child (http://obesityaction.org/).

\section{Aetiology of childhood obesity}

There are several factors that have potential effects on childhood obesity. The cause for childhood obesity includes:

\section{Changes in lifestyle}

\section{Unhealthy eating pattern and wrong choices of food}

Obesity occurs when energy intake is more than energy expenditure. Maintenance of proper body weight requires maintaining the balance between energy intake and energy expenditure. Roblin (2007) found that prevalence of overweight and obesity have doubled and tripled in the past three decades because of poor eating habits and changes in lifestyle. James and Kerr (2005) found that increased consumption of fast food, sugarsweetened soft drinks, processed food have been an important environmental factors contributing to childhood obesity. Poor quality diet such as high intake of fast food, soft drink and decreased consumption of fruits and vegetables, milk and milk products and whole grains are consumed by majority of children. These diets are able to adequately meet their nutrient requirements but is low in calcium and fibre and high in dietary fat and sodium according to Veugelers et al., (2005). Low intake of calcium and fibre and high in dietary fat and sodium increases the risk for chronic diseases like obesity, cardiovascular disease, diabetes etc. Low frequency in the habit of eating breakfast and low consumption of milk were found to be significantly associated with obesity.

\section{Fast food consumption and childhood obesity}

Kaushik et al., (2011) stated fast food as foods that are served ready to eat. Frequency of fast food consumption is increasing frequently among younger generation because of good taste, ready to eat form, easy availability and low cost. French (2003) stated that reducing the price of the product serve as effective strategy to increase the purchase of particular products. Likewise, low cost of fast food increases their frequency of consumption.

\section{Reason for increased fast food consumption}

Fast food chains are gaining popularity in nuclear families. Nowadays both parents are engaged in job. Because of busy schedule and limited time, mothers find difficulty in preparing regular meal for their families. They prefer skipping meals in home (www.human.cornell.edu/) and thus increases the frequency of eating out of fast food in children.

Nutritious and healthy food is now replaced 
by junk food and fast food. Fast food and restaurants serving fast foods such McDonald, Pizza Hut, KFC etc. are gaining popularity in children and adolescents through neighbours, school and TV advertisements. Also, junk food is available in and around school campus through variety of outlets. Cafeterias located near the school offers variety of junk food.

A lot of junk food advertisements are also shown in TV during children's serial break in attractive manner. Vaida (2013) stated a fact that highly nutritious and good quality food may be rejected if not properly presented while food is highly accepted if presented in attractive manner to the customers.

Also, advertisement is one of the effective tools of marketing to emotionally motivate the consumers to buy the products. Thus, TV advertisements showing junk food in attractive manner catches the children attention and encourages the child to try the taste of these foods at least once.

Prentice and Jebb (2003) found that the energy density of food is a key determinant of energy intake. Energy density of food (kilojoules per gram) is inversely proportional to energy cost (dollars per megajoule) of the food. Refined grains, added sugars and fats are good tasting, energy dense and available at low cost whereas fresh fruits and vegetables are nutrient dense and cost more. Drewnowski and Darmon (2005) stated that energy dense food and diets have low satiety value. This result in passive overeating, accidental consumption of excess energy and finally leads to weight gain.

\section{Harmful substances in Junk food}

Junk food may contain any of the following harmful substances such as

Trans Fat
According to Dave and Jain (2016), trans fat is a common type of unsaturated fat with at least one double bond in the trans configuration. It adds crisp and texture to food and increases the shelf life of the product. A high intake of trans fatty acids (TFAs) intake increases low density lipoprotein (LDL-C) and decreases high density lipoprotein (HDL-C) and thus associated with the increased risk for noncommunicable diseases such as coronary heart disease and the metabolic syndrome. Commercially available fast food contains saturated fatty acid and trans fatty acid in higher amount as compared to the amounts recommended by dietary guidelines. Asgary et al., (2009) and Nazari et al., (2012) stated that trans fatty acids like elaidic acid (C18:1 9t) and saturated fatty acids like stearic acid (C18:0) and palmitic (C16:0) acid are most common in junk food.

\section{Nitrite salts}

Nitrite Salts are added to foods such as in processed meat, bacon, corned beef, smoked fish, ham and sausages. It imparts unique flavour or colour to food, increases the shelf life and stability of the products. But these preservatives are carcinogenic and so possess many harmful effects on health.

\section{Saccharin and aspartame}

Saccharin is sodium ortho benzene or the calcium salts. It is 300 times sweeter than sucrose and is stable in wide variety of products under extreme processing conditions. Saccharin is non- nutritive sweetener, now being used to sweeten arecanut (supari and pan masala).

Aspartame is white, odourless, crystalline powder made by combining two amino acidaspartic acid and phenylalanine. It has sugarlike taste and 180 to 200 times sweeter than that of sucrose. It is used in soft drinks, instant 
coffee and tea and also in chewing gums as it enhances fruity flavour.

Saccharin and Aspartame are non- nutritive sweeteners, now being used in variety of food products but their consumption may be responsible for causing different types of cancer.

\section{Buttered-flavoured chemical}

Buttered-flavoured chemical called diacetyl is used in baked goods and candies, microwave popcorn and in variety of snack foods to impart an appetizing smell and buttery taste in them. But these chemicals have adverse effect on health as it increases the risk for Alzheimer's disease.

\section{Monosodium glutamate (MSG)}

Glutamate is a natural amino acid found in natural protein containing foods such as milk, mushrooms, fish, (www.globalhealingcenter.com/natural-health) meat and some vegetables. MSG is the sodium salt of glutamate. Monosodium glutamate (MSG) is used as flavour enhancer in the foods such as in masala/ spices that are used in noodles. It enhances or modifies the original flavour or aroma of the food without contributing its own flavour.

Once glutamate is ingested by us, our body is not able to distinguish between natural glutamates and glutamate of MSG. Human body metabolizes glutamate of MSG (e.g. added to a tomato sauce) in the same manner as it metabolizes glutamate found naturally in many foods (www.foodinsight.org/Content/76/pdf). MSG overexcites the cells of brain and causes damage to brain and various related diseases such as Parkinson's disease, Alzheimer's disease and learning disabilities.

\section{Sodium Benzoate, Potassium Benzoate and Butylated Hydroxyanisole (BHA)}

These are added in potato chips, cakes, fruit juices, bread, pie fillings etc. to prevent spoilage caused by moulds, bacteria and yeast. It maintains appearance, palatability and wholesomeness of the products but has harmful effects on health too.

\section{High Fructose Corn Syrup (HFCS)}

High Fructose Corn Syrup (HFCS) leads to obesity as it increases triglycerides level and aggravates fat storing hormones.

\section{Colouring agents}

Food colouring agents gives colour and appealing look to the food and also preserves the food. It is added to food products such as Ice- cream, cakes, fruit drinks and beverages, soft drinks, etc. But these are by-products of coal tar and thus increases the risk for certain types of cancer.

\section{Soft drink and childhood obesity}

Excess of soft drink consumption increases the risk for various diseases such as diabetes, heart disease, has adverse effect on bones and causes many other problems. According to one study by Mattes (1996) and DiMeglio and Mattes (2000), it was seen that person consuming soft drink had higher energy intake than those who were not consuming soft drink. This is so because when person consumes sugar - sweetened soft drink, individual's carbohydrate consumption in liquid form increases whereas person do not reduce their solid food intake. As a result, this in total leads to greater energy consumption and finally weight gain. Soft drink have high glycaemic index and hence causes rapid rise in blood glucose level after consumption. Vartanian et al., (2007) found that increase 
consumption of soft drink decreases the intake of milk, calcium and various other micronutrients and also increases the risk for various chronic diseases. Soft drink containing soda has high level of phosphate. So, by consuming excess of soft drink, phosphate consumption become more as compared to calcium intake and thus has adverse effect on bones.

\section{Fruit intake and obesity}

Rolls et al., (2005) stated that low-energydense diet provides low energy intake and maintains body weight. Energy density of diet can be reduced by increasing consumption of fruits and vegetables, soups, cooked grains etc. in the diet. Intake of low-energy-dense diet has benefit that it lowers the energy intake without decreasing the food volume, so, person consuming this diet don't feel hungry and able to reduce weight. Ledikwe et al., (2006) stated that person consuming low energy density diet had low intake of fat and higher intake of water and several other micronutrients such as calcium, folate, vitamin A, C, iron, potassium etc. According to BesRastrollo et al., (2006), dietary energy density of food was found to be positively correlated with all types of fat such as trans fat, saturated fat and inversely correlated with fruits and vegetables.

Tetens and Alinia (2009) suggested that consumption of fruits has beneficial role in prevention of obesity. Healthy People 2010 (Department of Health and Human Services, 2000) stated that high intake of fruits and vegetables are associated with low incidence of non - communicable disease (NCDs) such as diabetes, obesity, cardiovascular disease etc. Joint WHO/FAO Expert (2002) recommends 400 grams or aprox. 5 serving of fruits and vegetables/ person/ day. Healthy People (2010) recommend at least two servings of fruit and three servings of vegetables per day for general population.

\section{Sedentary lifestyle}

The factors like parental responsibility, overconsumption and media promotion of unhealthy foods, misuse/overuse of modern technology, children's lack of knowledge and motivation and sedentary lifestyle with no physical activity (Potestio et al., 2008) and watching television for more than 2 h/day (Nawab et al., 2014) is considered as most common cause of the childhood obesity. Electronic media like TV, Computer etc. have very significant effect on eating habits. The time spent in front of these electronic media and the content shown by them can be a reason for development of childhood obesity.

\section{Television and childhood obesity}

Vik et al., (2013) stated that chances of overweight and obesity increases in children consuming breakfast and dinner in front of television. Rey-López et al., (2011) and Scragg et al., (2006) stated watching television more than 2 hours per day increases the consumption of energy - dense snacks and beverages. Ramos et al., (2013) found children spending more than 120 minutes per day in television watching consume more fatty food and decreases their fruits and vegetable intake. This decreases their intake of complex carbohydrates, fibre, vitamins such as A, C and minerals such as calcium, iron, phosphorus, magnesium and potassium and their intake for saturated fat and cholesterol increases. Secondly, watching television while eating food acts as distraction leading to overconsumption according to Temple et al., (2007). More calories are consumed by children taking food in front of television and so associated with overweight and obesity.

Jenvey (2007) and Arcan (2013) found that Children of age 2 to 12 years watching television for more than two hours have 
minimum of 38 minutes of advertising each day. A major determinant of food preferences is taste. Eating habits and preferences for particular food develops during childhood and remains almost constant throughout adulthood. Exposure to TV advertisement in early years of life influences the eating habits and food preferences in children. Advertisements repeatedly showing particular food and their positive benefits influence the cognitively immature young children to eat unhealthy food with poor nutritional quality.

According to Rosiek et al., (2015), snacking and eating meal in front of television contributes to physical inactivity. TV viewing is normally a sedentary behaviour and sedentary lifestyle is one of the reasons for childhood obesity.

\section{Other electronic media and childhood obesity}

Like TV, electronic video game and computer use for moderate time is also responsible for obesity. Vandewater et al., (2004) stated that children spending moderate amount of time on computer or playing video game were having higher weight status, while those using a little of video game or computer were having lower weight status. Santaliestra-Pasías et al., (2014) found that children both boys and girls viewing television for $>4 \mathrm{~h}$ /day and using internet for recreational purpose had higher adherence to snacks and were less health conscious.

\section{Inadequate play area}

Centre for the Study of Social policy (2011) stated that reduced access to safe place for outdoor games in children causes decrease in physical activity among children. Majority of children don't get sufficient place for play or physical activity. Elimination or reduction of sufficient play area and physical education in school contributes towards childhood obesity.
Availability of safe, clean and less traffic bicycle lanes, parks, sidewalk area is linked to higher physical activity in children. However, Bhave et al., (2004) stated that busy and full of traffic lanes and availability of motorized vehicles among majority of parents prevents children from walking on these roads or going to school by cycling. Parents consider use of motorized vehicles as safe and quicker means for leaving their children to school. Also, majority of population are having limited access to well maintained or safe parks, lack of time for physical activity and lack of recreational facilities pushes the child towards sedentary lifestyle and increases incidence of childhood obesity.

\section{Obesogenic schools and Tution classes}

One of the very important factors contributing towards childhood obesity in India is excess of academic burden on children right from their childhood. Children are forced to study more, go for additional studies and to use their play time also, initially for getting admission in good schools and then for good performance in class and so on.

Murray and Ramstetter (2013) stated that vigorous play by children at the time of recess improves motor skills, provides joy and maintains active and healthy lifestyle in children. But, few schools don't have any playground or don't provide adequate recess time or play time to children. Busy time table for children right from nursery class and lack of playing area or play time in some schools decreases the level of physical activity in child and forces the child towards overweight and obesity.

\section{Genetic factors}

One of the important factors contributing towards childhood obesity is genetic factors. Reilly et al., (2005) found that parental obesity as strongest risk factor for childhood obesity. 
Table.1 Prevalence of childhood obesity in India

\begin{tabular}{|c|c|c|c|c|}
\hline & Age group & Place & Overweight & Obesity \\
\hline $\begin{array}{l}\text { Chhatwal et al., } \\
2004\end{array}$ & $9-15$ years & India & $14.2 \%$ & $11.1 \%$ \\
\hline \multirow[t]{2}{*}{$\begin{array}{l}\text { Marwaha et al., } \\
2006\end{array}$} & \multirow[t]{2}{*}{$5-18$ years } & \multirow[t]{2}{*}{ Delhi } & $\begin{array}{l}\text { USES } \\
\text { Boys }-16.75 \% \\
\text { Girls }-19.01 \%\end{array}$ & $\begin{array}{l}\text { USES } \\
\text { Boys }-5.59 \% \\
\text { Girls }-5.73 \%\end{array}$ \\
\hline & & & $\begin{array}{l}\text { LSES } \\
\text { Boys }-2.66 \% \\
\text { Girls }-2.14 \%\end{array}$ & $\begin{array}{l}\text { LSES } \\
\text { Boys }-0.42 \% \\
\text { Girls }-0.28 \%\end{array}$ \\
\hline $\begin{array}{l}\text { Sharma, et al., } \\
2007\end{array}$ & $4-17$ years & Delhi & $22 \%$ & $6 \%$ \\
\hline $\begin{array}{l}\text { Mahajan et.al., } \\
2011\end{array}$ & $6-12$ years & Puducherry & $4.41 \%$ & $2.12 \%$ \\
\hline \multirow{2}{*}{$\begin{array}{l}\text { Nayak and } \\
\text { VinodBhat, } 2011\end{array}$} & \multirow[t]{2}{*}{$10-16$ years } & \multirow{2}{*}{$\begin{array}{l}\text { Udupi district of } \\
\text { Karnataka, South } \\
\text { India. }\end{array}$} & $7 \%$ & $5 \%$ \\
\hline & & & \multicolumn{2}{|c|}{$\begin{array}{l}\text { Note: Higher BMI found among children } \\
\text { in the age of } 10-12 \text { years and among } \\
\text { girls than the boys. }\end{array}$} \\
\hline $\begin{array}{l}\text { Siddiqui } \quad \text { and } \\
\text { Bose, 2012 }\end{array}$ & $7-14$ years & Madhya Pradesh & & $\begin{array}{l}\text { Overall- }-14.97 \% \\
\text { Boys }-6.81 \% \\
\text { Girls }-8.16 \% \\
\end{array}$ \\
\hline $\begin{array}{l}\text { Longkumer, } \\
\text { 2013. }\end{array}$ & $8-15$ years & $\begin{array}{l}\text { Nagaland, North - } \\
\text { East India }\end{array}$ & $\begin{array}{l}\text { Overall }-2.28 \% \\
\text { Boys }-2.08 \% \\
\text { Girls }-2.48 \% \\
\end{array}$ & \\
\hline \multirow[t]{2}{*}{ Vaida, 2013} & \multirow[t]{2}{*}{$6-12$ years } & \multirow{2}{*}{$\begin{array}{l}\text { Anantnag district } \\
\text { of Jammu and } \\
\text { Kashmir }\end{array}$} & Govt. School - 4\% & Govt. School - 0\% \\
\hline & & & $\begin{array}{l}\text { Private school - } \\
14 \%\end{array}$ & $\begin{array}{l}\text { Private school - } \\
6 \%\end{array}$ \\
\hline Shah et al., 2013 & $10-12$ years & $\begin{array}{l}\text { Mehsana district of } \\
\text { Gujarat }\end{array}$ & $\begin{array}{l}\text { Overall }-33.88 \% \\
\text { Boys }-34.82 \% \\
\text { Girls }-32.95 \%\end{array}$ & $\begin{array}{l}\text { Overall }-10.67 \% \\
\text { Boys }-13.39 \% \\
\text { Girls }-7.95 \%\end{array}$ \\
\hline Bansal et al., 2013 & $\begin{array}{l}\begin{array}{l}\text { School } \\
\text { children }\end{array} \\
-\quad \text { age }\end{array}$ & Jaipur & $\begin{array}{l}\text { Overall }-14.83 \% \\
\text { Boys }-13.92 \% \\
\text { Girls }-16.23 \% \\
\end{array}$ & $\begin{array}{l}\text { Overall }-5.69 \% \\
\text { Boys }-5.11 \% \\
\text { Girls }-6.58 \% \\
\end{array}$ \\
\hline $\begin{array}{l}\text { Sargunam } \\
\text { et al., } 2014\end{array}$ & $5-10$ years & $\begin{array}{l}\text { Tirunelveli District } \\
\text { of Tamil Nadu }\end{array}$ & $\begin{array}{l}\text { Boys }-9.9 \% \\
\text { Girls }-12 \%\end{array}$ & Girls $-6.3 \%$ \\
\hline Jacob, 2014 & $6-15$ years & $\begin{array}{l}\text { Ernakulam district } \\
\text { of Kerala }\end{array}$ & & $\begin{array}{l}\text { Overall }-3.10 \% \\
\text { Boys }-3.35 \% \\
\text { Girls }-2.85 \% \\
\end{array}$ \\
\hline Ashok et al., 2014 & $6-12$ years & Mysore, Karnataka & $8.4 \%$ & $4.10 \%$ \\
\hline \multirow{2}{*}{$\begin{array}{l}\text { Mishra et al., } \\
2015\end{array}$} & \multirow[t]{2}{*}{$10-12$ years } & \multirow[t]{2}{*}{ Sambalpur, Odisha } & \multicolumn{2}{|l|}{ Overall - $9.6 \%$} \\
\hline & & & Males $-9 \%$ & Females- $10.7 \%$ \\
\hline Dubal, 2015. & $6-12$ years & Gujarat & $19.4 \%$ & $13.5 \%$ \\
\hline $\begin{array}{l}\text { Prashanth and } \\
\text { Remya, 2016 }\end{array}$ & $6-12$ years & $\begin{array}{l}\text { Kolenchery, } \\
\text { Kerala }\end{array}$ & & $\begin{array}{l}\text { Overall }-6.70 \% \\
\text { Boys }-4.10 \% \\
\text { Girls }-6.80 \%\end{array}$ \\
\hline $\begin{array}{l}\text { Gupta and } \\
\text { Rathore, } 2016\end{array}$ & $6-14$ years & Lucknow & $6.19 \%$ & $5.10 \%$ \\
\hline
\end{tabular}


Table.2 Definitions related to fast foods

\begin{tabular}{|l|l|l|}
\hline Type of food & Definition & Examples \\
\hline Fast food & $\begin{array}{l}\text { Foods sold in a restaurant } \\
\text { or store which are rapidly } \\
\text { prepared and quickly } \\
\text { served in a packaged form } \\
\text { hamburgers, pizzas, fries, } \\
\text { for take away. }\end{array}$ & $\begin{array}{l}\text { nuggets. } \\
\text { Indian foods like pakora, } \\
\text { samosa, namkeen etc. }\end{array}$ \\
\hline Junk food & $\begin{array}{l}\text { Energy dense foods with } \\
\text { high sugar/ fat/ salt content } \\
\text { and low nutrient value in } \\
\text { terms of etc. protein, fiber, } \\
\text { vitamin and mineral } \\
\text { content. }\end{array}$ & $\begin{array}{l}\text { Chips, } \\
\text { icecream, soft drinks, }\end{array}$ \\
\hline Instant foods & $\begin{array}{l}\text { Foods that undergo special } \\
\text { processing that are ready to } \\
\text { be served once dissolved or } \\
\text { dispersed in a liquid with } \\
\text { low cooking time }\end{array}$ & $\begin{array}{l}\text { Noodles, corn flakes, } \\
\text { soup powder. }\end{array}$ \\
\hline Street foods & $\begin{array}{l}\text { Ready to eat foods and } \\
\text { beverages prepared and } \\
\text { sold by hawkers or vendors } \\
\text { in streets or other public } \\
\text { places. }\end{array}$ & $\begin{array}{l}\text { Chaat, gol guppa, } \\
\text { samosa, tikki, noodles, } \\
\text { chowmein, burger etc. }\end{array}$ \\
\hline
\end{tabular}

Magnusson and Rasmussen (2002) stated that if both parents are obese then probability that child will be obese is highly elevated. Lyon $e t$ al., (2005) and Stein et al., (2011) stated that risk for obesity ranges from $30 \%$ to $70 \%$ if parents are obese or even if close relatives are obese. Obesity genes act as recessive genes. Obesity are called complex genetic traits because each gene responsible for causing obesity have only small contribution to increase in body weight but these genes together are responsible for increased BMI if individual carrying obesity genes respond to faulty dietary habits and sedentary lifestyle.

All humans have almost the same genetic material. There is very slight difference in genome from person to person. Since, most genetic variation in human is common, actual genes responsible for causing obesity is still not very clear. Two approaches namely linkage analysis and association studies have been used to find variants causing obesity. Several studies found that mutation in leptin gene causes severe obesity syndromes. Genes such as leptin, proopiomelanocotrin, melanocortin 4 receptor (MC4R), and BardetBiedel syndrome loci have been found to be altered in obesity syndrome. So, obesity is very common disease occurring due to multiple factors with genetic factors playing a very strong role.

Genetically three types of obesity i.e. monogenic, syndromic and polygenic obesity were defined by Puiu et al., (2013). Monogenic obesity is defined as obesity occurring due to single gene mutation e.g. congenital leptin deficiency. Leptin is a hormone derived from adipocytes and is secreted in proportion to body fat content. However, in case of leptin deficiency, 
hyperphagia occurs and energy intake increases. Thus, in case of food abundancy, mutation in single gene is responsible for obesity. Syndromic obesity includes disorders related to Mendelian inheritance and person is clinically obese in this. Third one is polygenic obesity, most common type and is responsible for causing obesity in majority of children. In this, individual genes are susceptible to an environment and when energy intake is more than expenditure, it leads to obesity.

\section{Childhood obesity prevention}

The alarming global rise in childhood obesity has been accompanied by numerous prevention strategies. These are aimed at multiple levels and range from macro-level policy or environmental change to targeted interventions focusing on individual behaviour change as any single intervention separately will not be able to prevent childhood obesity. Formulation of policies that in total support development of healthy communities, improved accessibility of healthy food to all children and healthy school initiatives can have significant impact on prevention of childhood obesity. According to Castaño et $a l ., 2004$, it is found that nutrition education, promotion of physical activity along with behaviour modifications and decrease in sedentary lifestyle of the child could be the factors in the prevention of childhood obesity.

\section{References}

AlNuaim, A.R.; Bamgboye, E.A. and AlHerbish, A. 1996. The pattern of growth and obesity in Saudi Arabian male school children. International Journal of Obesity, 20: $1000-1005$.

Arcan, C. 2013. Television (TV) and TV Advertisement Influences on Children's Eating Behaviour. Child NutritionEncyclopedia on early childhood development. http://www.childencyclopedia.com/child- nutrition/according-experts/television-tvand-tv-advertisement-influenceschildrens-eating. Accessed on 16 April, 2016.

Asgary, S.; Nazari, B.; Sarrafzadegan, N.; Parkhideh, S.; Saberi, S.; Esmaillzadeh, A. and Azadbakht, L. 2009. Evaluation of fatty acid content of some Iranian fast foods with emphasis on trans fatty acids. Asia Pacific Journal of Clinical Nutrition, 18 (2): 187- 192.

Ashok, N.C.; Kavitha, H.S. and Kulkarni, P. 2014. A comparative study of nutritional status between government and private primary school children of Mysore city. International Journal of Health \& Allied Sciences, 3(3): 164 - 169.

Baghel, S.S.; Dobhal, N. and Raghuvanshi, R.S. 2015. Prevalence of obesity among school going children of Pantnagar. Asian Journal of Home Science, 10(1): 133 136.

Bansal, A.K.; Manohar, R.; Yadav, R.; Sharma, D.; Yadav, N. and Lohani, H. 2013. Prevalence of obesity and its lifestyle risk factors in school-age children in Jaipur. The Indian Journal of Research and Reports in Medical Sciences, 3(2): 16 19.

Bes-Rastrollo, M.; Dam, R.M.V.; MartinezGonzalez, M.A.; Li, T.Y.; Sampson, L.L. and $\mathrm{Hu}, \mathrm{F} . \mathrm{B} .2008$. A prospective study of dietary energy density and weight gain in women. American Journal of Clinical Nutrition, 88(3): 769 - 777.

Bhave, S.; Bavdekar, A. and Otiv, M. 2004. IAP National Task Force for Childhood Prevention of Adult Diseases: Childhood Obesity. Indian pediatrics, 41: $559-575$.

Carlyle, M.; Jones, O.B.; Kuo, J.J.; Hall, J.E. 2002. Chronic cardiovascular and renal actions of leptin: role of adrenergic activity. Hypertension, 39: 496-501.

CDC growth charts: United States. 2000. Advance data from vital and health statistics. No.314 National Center for Health Statistics: Atlanta.

Centre for the Study of Social policy. 2011. Results-based public policy strategies for 
preventing childhood obesity. pp: $8-13$.

Chhatwal, J.; Verma, M. and Riar, S.K. 2004. Obesity among pre-adolescent and adolescents of a developing country (India). Asia Pac J Clin Nutr, 13 (3): 231235.

Dave, S. and Jain, A. 2016. A Paper on Problems Generated By Junk Food in India. International Journal of Computational Engineering Research (IJCER), 6(1): 10-20.

Day, C. and Bailey, C.J. 2011. Obesity in the pathogenesis of type 2 diabetes. British Journal of Diabetes \& Vascular Disease, 11 (2): 55- 61.

DiMeglio, D.P. and Mattes, R.D. 2000. Liquid versus solid carbohydrate: effects on food intake and body weight. International Journal of Obesity, 24(6): 794-800.

Drewnowski, A. and Darmon, N. 2005. The economics of obesity: dietary energy density and energy cost. The American Journal of Clinical Nutrition, 82(1): 265S273S.

Dubal, J. 2015. Prevalence of overweight and obesity in primary school children. Journal of Advanced Medical and Dental Sciences Research, 3(6): S58 - S61.

Dwyer, T and Blizzard, C.L. 1996. Defining obesity in children by biological endpnt rather than population distribution. Int $J$ Obes Relat Metab Disord, 20: 472-480.

Fiorino, E.K. and Brooks, L.J. 2009. Obesity and respiratory diseases in childhood. Clinics In Chest Medicine, 30 (3): 601608.

Freedman, D.S.; Dietz, W.H.; Srinivasan, S.R. and Berenson, G.S. 1999. The Relation of Overweight to Cardiovascular Risk Factors among Children and Adolescents: The Bogalusa Heart Study. Pediatrics, 103 (6): 1175-1182.

French, S.A. 2003. Pricing effects on food choices. Journal of nutrition. 133(3): 841S-843S.

Gupta, S. and Rathore, R. 2016. Prevalence and Factors Influencing Obesity in Children aged 6-14 Years belonging to Upper Middle Income Group of Lucknow City.
International Journal of Contemporary Medical Research, 3(4): 1055 - 1057.

Hannon, T.S.; Rao, G. and Arslanian, S.A. 2005. Childhood Obesity and Type 2 Diabetes Mellitus. Pediatrics, 116 (2).

Hatami, M.; Taib, M.N.M.; Djazayery, A.; Mojani, S.M. and Mejlej, H.F. 2015. Relationship between body image, body dissatisfaction and weight status in Iranian adolescents. Archives of Obesity, 1: 1-7.

Higgins, P.B.; Gower, B.A.; Hunter, G.R. and Goran, M.I. 2001. Defining health-related obesity in prepubertal children. Obesity Research \& Clinical Practice, 9(4): 233 240.

Ho,T. F. 2009. Cardiovascular Risks Associated With Obesity in Children and Adolescents. Annals Academy of Medicine, 38 (1): 48- 56.

http://obesityaction.org/wpcontent/uploads/Childhood-Obesity-andStigma.pdf. childhood obesity and stigma. Accessed on 9 Feb. 2016.

Ibarra, J. 2009. Obesity and Cardiovascular Disease. The Journal of Lancaster General Hospital, 4 (4): 130- 133.

Jacob, S.K. 2014. Prevalence of Obesity and Overweight among School Going Children in Rural Areas of Ernakulam District, Kerala State India. International Journal of Scientific Study, 2(1): 16 - 19.

James, J. and Kerr, D. 2005. Prevention of childhood obesity by reducing soft drinks. International Journal of Obesity, 29: S54-S57.

Jenvey, V.B. 2007. The relationship between television viewing and obesity in young children: a review of existing explanations. Early Child Development and Care, 177(8): 809- 820.

Kaur, S.; Sachdev, H.P.; Dwivedi, S.N.; Lakshmy, R. and Kapil, U. 2008. Prevalence of overweight and obesity amongst school children in Delhi, India. Asia Pacific Journal of Clinical Nutrition, 17(4): 592 - 596.

Kaushik, J.S.; Narang, M. and Parakh, A. 2011. Fast Food Consumption in Children. Indian Pediatrics, 48: 97- 101. 
Kumar, R. and Sharma, S.K. 2013. Trends of communicable and non-communicable morbidities in uttarakhand state: a systemic review. Indian Journal of Community Health, 25(2): 178 - 187.

Ledikwe, J.H.; Blanck, H.M.; Khan, L.K.; Serdula, M.K.; Seymour, J.D.; Tohill, B.C. and Rolls, B.J. 2006. Low-energydensity diets are associated with high diet quality in adults in the United States. Journal of the American Dietetic Association, 106(8): 1172 - 1180.

Longkumer, T. 2013. Physical Growth and Nutritional Status among Ao Naga Children of Nagaland, Northeast India. Journal of Anthropology, Article ID 291239: 6.

Lyon, H.L. and Hirschhorn, J.N. 2005. Genetics of common forms of obesity: a brief overview. American Journal of Clinical Nutrition, 82(1): 215S - 217S.

Magnusson, P.K.E. and Rasmussen, F. 2002. Familial resemblance of body mass index and familial risk of high and low body mass index. A study of young men in Sweden. International journal of obesity and related metabolic disorders, 26(9): 1225-1231.

Mahajan, P.B.; Purty, A.J.; Singh, Z.; Cherian, J.; Natesan, M.; Arepally, S. and Senthilvel, V. 2011. Study of Childhood Obesity Among School Children Aged 6 to 12 Years in Union Territory of Puducherry. Indian J Community Med., 36(1): $45-50$.

Martins, A. D.; Moreira, A. C.; Sá, R.; Monteiro, M. P.; Sousa, M.; Carvalho, R. A.; Silva, B. M.; Oliveira, P. F.; Alves, M. G. 2015. Leptin modulates human Sertoli cells acetate production and glycolytic profile: a novel mechanism of obesity-induced male infertility? Biochimica et Biophysica Acta : ELSEVIER, 1852 (9) : 1824-1832.

Marwaha, R.K.; Tandon, N.; Singh, Y.; Aggarwal, R.; Grewal, K. and Mani, K. 2006. A Study of Growth Parameters and Prevalence of Overweight and Obesity in School Children from Delhi. Indian pediatrics, 43: 943 - 952.

Mattes, R.D. 1996. Dietary compensation by humans for supplemental energy provided as ethanol or carbohydrate in fluids. Physiology \& Behavior, 59(1): $179-187$.

Midha, T.; Nath, B.; Kumari, R.; Rao, Y.K. and Pandey, U. 2012. Childhood Obesity in India: A Meta-Analysis. The Indian Journal of Pediatrics, 79 (7): 945-948.

Mishra, A.K.; Acharya, H.P. and Giri, R.C. 2015. Prevalence of obesity among school children aged 10 to 12 years in Sambalpur. International Journal of Medical Science and Public Health, 4(10): 1366 - 1368.

Murray, R. and Ramstetter, C. 2013. The Crucial Role of Recess in School. Pediatrics, 131(1): 183 - 188 .

Murugan, A.T. and Sharma, G. 2008. Obesity and respiratory diseases. Chronic Respiratory Disease, 5(4): 233- 242.

Must, A. and Anderson, S.E. 2006. Body mass index in children and adolescents: considerations for population-based applications. International Journal of Obesity, 30: 590 - 594.

Nawab, T; Khan, Z.; Khan, I.M. and Ansari, M.A. 2014. Influence of behavioral determinants on the prevalence of overweight and obesity among school going adolescents of Aligarh. Indian $J$ Public Health, 58 (2): 121- 124.

Nayak, B.S. and VinodBhat, H. 2011. Prevalence of Overweight / Obesity among School Children In Karnataka, South India. International Journal of Public Health Research, Special Issue: $180-184$.

Nazari, S.; Asgary, S.and Azadbakht, L. 2012. Fatty acid analysis of Iranian junk food, dairy, and bakery products: Special attention to trans-fats. Journal of Research in Medical Sciences, 17(10): 952- 957.

Pallan, M. J. 2010. Childhood Obesity And Its Prevention In Primary School-Aged Children: A Focus On South Asian Communities In The Uk. Thesis, Ph.D. The University of Birmingham, $5 \mathrm{p}$.

Pallan, M.J.; Hiam, L.C.; Duda, J.L. and Adab, 
P. 2011. Body image, body dissatisfaction and weight status in south asian children: a cross-sectional study. BMC Public Health, 11(21): 1- 8.

Potestio, M.L.; McLaren, L.; Vollman, A.R. and DoyleBaker, P.K. 2008. Childhood Obesity: Perceptions Held by the Public in Calgary, Canada. Canadian Journal of Public Health, 99 (2): 86-90.

Prashanth, P.V. and Remya J. 2016. Prevalence of Obesity among 6 to 12 Year Old School Children in Kolenchery, Kerala. International Journal of Nursing Care, 4(1): 19- 20.

Prentice, A.M. and Jebb, S.A. 2003. Fast foods, energy density and obesity: a possible mechanistic link. Obesity Reviews, 4(4): 187-94.

Puiu, M.; Emandi, A.C. and Arghirescu, S. 2013. Genetics and Obesity. pp. 275 283.

Qatanani, $\mathrm{M}$ and Lazar, M.A. 2007. Mechanisms of obesity-associated insulin resistance: many choices on the menu. Genes and development, 21: 1443- 1455.

Ranjani, H.; Mehreen, T.S.; Pradeepa, R.; Anjana, R.M.; Garg, R.; Anand, K. and Mohan, V. 2016. Epidemiology of childhood overweight \& obesity in India: A systematic review. Indian Journal of Medical Research, 143(2): 160 - 174.

Ramos, E.; Costa, A.; Araújo, J.; Severo, M. and Lopes, C. 2013. Effect of television viewing on food and nutrient intake among adolescents. Nutrition, 29 (11- 12): 1362-1367.

Reilly, J.J.; Armstrong, J.; Dorosty, A.R.; Emmett, P.M.; Ness, A.; Rogers, I.; Steer, C. and Sherriff, A. 2005. Early life risk factors for obesity in childhood: cohort study. BMJ, 330(7504): 1357.

Réthoret-Lacatis, C. and Janssens, J.P. 2008. Obesity and respiratory disorders. Revue médicale Suisse, 4(180): 2512- 2514.

Rey-López, J.P.; Vicente-Rodríguez, G.; Répásy, J.; Mesana, M.I.; Ruiz, J.R.; Ortega, F.B.; Kafatos, A.; Huybrechts, I.; Cuenca-García, M.; León, J.F.; GonzálezGross, M.; Sjöström, M.; Bourdeaudhuij,
I. and Moreno, L.A. 2011. Food and drink intake during television viewing in adolescents: the Healthy Lifestyle in Europe by Nutrition in Adolescence (HELENA) study. Public Health Nutrition, 14(9): 1563-1569.

Roblin, L. 2007. Childhood obesity: food, nutrient, and eating-habit trends and influences. Applied Physiology, Nutrition, and Metabolism, 32 (4): 635-645.

Rofey, D.L.; Kolko, R.P.; Iosif, A.M.; Silk, J.S.; Bost, J.E.; Feng, W.; Szigethy, E.M.; Noll, R.B.; Ryan, N.D. and Dahl, R.E. 2009. A Longitudinal Study of Childhood Depression and Anxiety in Relation to Weight Gain. Child Psychiatry and Human Development, 40 (4): 517-526.

Rolls, B.J.; Drewnowski, A. and Ledikwe, J.H. 2005. Changing the energy density of the diet as a strategy for weight management. Journal of the American Dietetic Association, 105(5 suppl 1): S98 - 103.

Rosiek, A.; Maciejewska, N.F.; Leksowski, K.; Rosiek-Kryszewska, A. and Leksowski, L. 2015. Effect of Television on Obesity and Excess of Weight and Consequences of Health. International Journal of Environmental Research and Public Health, 12: 9408-9426.

Russell-Mayhew, S.; McVey, G.; Bardick, A. and Ireland, A. 2012. Mental Health, Wellness, and Childhood Overweight/Obesity. Journal of Obesity, Article ID 281801: 9.

Sánchez-Villegas, A.; Pimenta, A.M.; Beunza, J.J.; Guillen-Grima. F.; Toledo, E. and Martinez-Gonzalez, M.A. 2010. Childhood and Young Adult Overweight/ Obesity and Incidence of Depression in the SUN Project. Obesity- A Reasearch Journal, 18(7): 1443- 1448.

Santaliestra-Pasías, A.M.; Mouratidou, T.; Huybrechts, I.; Beghin, L.; CuencaGarcía, M.; Castillo, M.J.; Galfo, M.; Hallstrom, L.; Kafatos, A.; Manios, Y.; Marcos, A.; Molnar, D.; Plada, M.; Pedrero-Chamizo, R.; Widhalm, K.; Bourdeaudhuij, I.D. and Moreno, L.A. 2014. Increased sedentary behaviour is 
associated with unhealthy dietary patterns in European adolescents participating in the HELENA study. European Journal of Clinical Nutrition, 68: 300- 308.

Sargunam, J.H.; Fathima, M.A.S.H. and Mohamed, M.I.F. 2014. A Study on Growth Parameters and Prevalence of Overweight and Obesity among School Going Children (5-10 Years) In Tirunelveli District. IOSR Journal of Nursing and Health Science, 3(2): 7 - 14.

Scragg, R.; Quigley, R. and Taylor, R. 2006. Does watching TV contribute to increased body weight and obesity in children? A report prepared by the Scientific Committee of the Agencies for Nutrition Action.

Shah, J.S.; Patel, P.K. and Patel, B. 2013. Determinants of overweight and obesity among school children in Mehsana District, India. Annals of Tropical Medicine and Public Health, 6(4): 408 412.

Sharma, A.; Sharma, K. and Mathur, K.P. 2007. Growth pattern and prevalence of obesity in affluent schoolchildren of Delhi. Public Health Nutr., 10(5): 485 - 491.

Siddiqui, N.I. and Bose, S. 2012. Prevalence and trends of obesity in Indian school children of different socioeconomic class. Indian Journal of Basic \& Applied Medical Research, 5(2): 393- 398.

Stang, J. and Story, M. 2005. Nutrition screening, assessment and Intervention In: Guidelines for adolescent nutrition services. pp- 39.

Stein, Q.P.; Mroch, A.R.; De Berg, K.L. and Flanagan, J.D. 2011. The influential role of genes in obesity. South Dakota medicine, 12(5): 17.

Strauss, R.S. 2000. Childhood Obesity and SelfEsteem. Pediatrics, 105 (1): 1- 5.

Temple, J.L.; Giacomelli, A.M.; Kent, K.M.; Roemmich, J.N. and Epstein, L.H. 2007. Television watching increases motivated responding for food and energy intake in children. The American Journal of Clinical Nutrition, 85 (2): 355- 361.

Tetens, I. and Alinia, S. 2009. The role of fruit consumption in the prevention of obesity. Journal of Horticultural Science \& Biotechnology, Special Issue 47-51: 47 51.

Vaida, N. 2013. Prevalence of Fast Food Intake among Urban Adolescent Students. The International Journal of Engineering and Science (IJES), 2(1): 353- 359.

Vaida, N. 2013. Prevalence of Obesity among Children Studying In Government and Private Schools in District Anantnag Age Group (6-12 Years). IOSR Journal of Pharmacy, 3(1): $4-11$.

Vandewater, E.A.; Shim, M. and Caplovitz, A.G. 2004. Linking obesity and activity level with children's television and video game use. Journal of Adolescence, 27: 71-85.

Vartanian, L.R.; Schwartz, M.B. and Brownell, K.D. 2007. Effects of Soft Drink Consumption on Nutrition and Health: A Systematic Review and Meta-Analysis. American Journal of Public Health, 97(4): $667-675$.

Veugelers, P.J.; Fitzgerald, A.L. and Johnston, E. 2005. Dietary Intake and Risk Factors for Poor Diet Quality Among Children in Nova Scotia. Canadian Journal of Public Health, 96 (3): 212- 216.

Vik, F.N.; Bjørnara, H.B.; Øverby, N.C.; Lien, N.; Androutsos, O.; Maes, L.; Jan, N.; Kovacs, E.; Moreno, L.A.; Dössegger, A.; Manios, Y.; Brug, J. and Bere, E. 2013. Associations between eating meals, watching TV while eating meals and weight status among children, ages $10-$ 12 years in eight European countries: the ENERGY cross-sectional study. International Journal of Behavioral Nutrition and Physical Activity, 10(58): 110.

World Health Organization. 2000. Obesity: Preventing and managing the global epidemic, Report of a WHO consultation. WHO:Geneva. WHO Technical Report Series, No. 894.

www.foodinsight.org/Content/76/Glutamateand-Monosodium-Glutamate.pdf. Glutamate and Monosodium Glutamate: 
Examining the Myths. International Food Information Council Foundation. Accessed on 27 April, 2016.

www.globalhealingcenter.com/naturalhealth/harmful-effects-of-monosodium glutamate-msg/. The Harmful Effects of Monosodium Glutamate (MSG) by Dr. Edward Group. Accessed on 17 April, 2016.

www.human.cornell.edu/outreach/upload/CHE_ DNS_Devine_Time.pdf. Time Pressures on Employed Parents Affect Families' Diets - by Devine, C. Accessed on 17 April, 2016.

www.jyi.org/issue/literature-review-a-21stcentury-epidemic-childhood-obesity-innorth-america/. Literature Review- A $21^{\text {st }}$ century Epidemic: Childhood Obesity in North America. Accessed on 9 April. 2016.

www.niddk.nih.gov/health-information/healthtopics/Diabetes/insulin-resistanceprediabetes/Documents/Insulin_Resistanc e_Prediabetes-508.pdf. Insulin Resistance and Prediabetes .National Institute of Diabetes and digestive and kidney diseases. Accessed on 7 April 2016.

www.noo.org.uk/uploads/doc789_40_noo_BMI. pdf. 2009. Body Mass Index as a measure of obesity. Accessed on 29 Mar. 2016.

www.opposingviews.com/i/health/food-andnutrition/dieting/how-exactly-doesobesity-cause-diabetes. How Exactly Does Obesity Cause Diabetes?. Accessed on 9 April. 2016.

www.who.int/mediacentre/factsheets/fs311/en/. Accessed on 5 oct. 2015.

www.who.int/topics/obesity/en/. Health topicsObesity. Accessed on 29 Mar. 2016.

Yagnik, P.J.; McCormick, D.P.; Ahmad, N.; Schecter, A.J. and Harris, T.R. 2014. Childhood and adolescent obesity and depression: A systematic literature review. International Archives of Integrated Medicine, 1(2): 23- 33.

Yaturu, S. 2011. Obesity and type 2 diabetes. Journal of Diabetes Mellitus, 1 (4): 7995.

\section{How to cite this article:}

Anugya Bharti and Kalpana Kulshrestha. 2019. Childhood Obesity: An Overview. Int.J.Curr.Microbiol.App.Sci. 8(01): 963-980. doi: https://doi.org/10.20546/ijcmas.2019.801.105 